\title{
Article
}

\section{Quality Management Systems and Working Capital SMEs in GPO-A Case of Poland}

\author{
Grzegorz Zimon ${ }^{1}\left(\mathbb{D}\right.$ and Dominik Zimon ${ }^{2, *(\mathbb{D})}$ \\ 1 Department of Finance, Banking and Accountancy, The Faculty of Management, Rzeszow University of \\ Technology, 35-959 Rzeszow, Poland; gzimon@prz.edu.pl \\ 2 Department of Management Systems and Logistics, Rzeszow University of Technology, \\ 35-959 Rzeszow, Poland \\ * Correspondence: zdomin@prz.edu.pl
}

Received: 10 August 2020; Accepted: 24 September 2020; Published: 1 October 2020

check for updates

\begin{abstract}
Working capital is designed to provide enterprises with financial security. Its level depends on the strategy of managing individual elements of working capital. An appropriate management strategy allows companies to obtain added working capital. Working capital management is a difficult process as it concerns both current assets and current liabilities. Therefore, company managers are constantly looking for solutions, methods and tools that will help them to manage their working capital. A quality management system is the one that facilitates control over the management of individual elements that create net working capital. The introduction of appropriate procedures derived from quality management systems in specific areas is a great support for creating a positive net working capital. The aim of this paper is to show how the introduction of quality management systems can positively affect the level of working capital. The article presents how quality management systems allow for optimizing the level of individual components, creating a positive net working capital. The research was carried out on a group of 102 Polish small trading companies operating in the same industry. The enterprises were divided into two groups of companies applying the quality management system and of those that did not use such systems. Based on the financial statements for the years 2017-2019 and by means of appropriately selected financial ratios, an analysis of the impact of quality management systems on net working capital was carried out. The results in some areas of management of individual components of net working capital in different groups of enterprises were compared. The research was carried out with the application of appropriate statistical methods. The analysis showed that enterprises using quality management systems managed working capital more efficiently. In the literature, the subject of the impact of quality management systems on working capital is not popular. This paper may be a source for further, extended research and considerations regarding the impact of quality management on the level of working capital in enterprises.
\end{abstract}

Keywords: working capital; quality; management; small-and medium-sized enterprises; Poland

\section{Introduction}

Management of net working capital is the management of the company finances in the short term. The basic level of net working capital in an enterprise is influenced by two basic elements, namely current assets and current liabilities. These two basic elements consist of a number of components that create current assets and short-term liabilities. Managing these components is a process that continues without interruption. The decisions regarding the sale of goods, materials, purchase organization and inventory management are a continuous process and are closely related to working capital. When simplifying, working capital management is used to determine the appropriate level of current assets and short-term liabilities as well as their structure. It can be stated that it is the result of developed 
management strategies for individual elements affecting the level of working capital. The problem with working capital management is to determine its optimal level. In an enterprise, working capital can be positive, negative or theoretically zero. Ideally, a company should have positive working capital, which is, in a sense, a buffer that protects it from losing financial liquidity. However, when the level is too high, this may lead to unjustified freezing of cash in current assets. A low level is the risk of problems with settling current liabilities. Therefore, there is a problem with determining the optimal value. To achieve this level, it is worth using appropriate measures that will allow comparison of the demand for working capital in a given period with its level. However, it should be remembered that lowering the level or increasing the level of net working capital refers to decisions that are most often made in the area related to receivables from customers, inventories or liabilities to suppliers. Actions taken by a company in a given area can actually result in setting a model level of working capital, but they can also generate unjustified costs. In the case of managing receivables from customers, some steps may be taken to speed up the process of collecting receivables. This can cause the loss of contractors who will choose a different supplier with a better trade credit offer. Shortening the repayment period may be costly if the company in return has to finance its operations with a more expensive bank loan. Its extension beyond the payment deadline in turn entails the risk of the appearance of penalty interest. In the area of warehouse management, switching to the Just in Time method carries the risk of holding up production or sales when there are shortages of materials for production or goods for which there is a demand.

Therefore, the working capital management process is very complicated and is fundamental for building the financial security of enterprises. The subject of working capital management, and thus the management of trade credit and risk in SMEs, is currently a subject that is being extensively discussed in studies on the V4 countries (Cicea et al. 2019; Kontus and Mihanovic 2019; Ključnikov et al. 2019; Otrusinova and Kulleova 2019; Sofiina 2020; Susilowati et al. 2020). This is due to the fact that there are developing markets and substantial foreign concerns regarding these markets, which increases competition in virtually every industry. This is especially dangerous for SMEs and therefore it is so important for these companies to create appropriate working capital management strategies that will ensure their financial security. An increase in competition in the market, the uncertain economic situation and the specter of the expansion of trade conflicts on the US-China route mean that business managers introduce certain methods and tools that will ensure a positive level of net working capital. Some enterprises start operating together in the market within multi-stakeholder organizations. This cooperation allows enterprises to raise the level of net working capital (Zimon 2018; Dhole et al. 2019). There are enterprises that introduce quality management systems to improve the management of individual elements affecting the amount of working capital. This is to improve the management process, mainly inventory or the process of debt collection. In general, quality management systems bring tangible results in manufacturing enterprises. In commercial enterprises, their usefulness is lower and difficult to assess. On the other hand, in the case of small commercial enterprises, it is very difficult to investigate because few commercial units decide to introduce quality management systems. Standardized quality management systems undoubtedly affect many aspects affecting the financial situation of enterprises (Chatzipetrou and Moschidis 2017). This is due to the fact that quality management organizes the functioning of key processes in enterprises, minimizes the number of errors, reduces the costs of the so-called "poor quality" and supports the effective implementation of tasks (Chiarini et al. 2020; Dellana et al. 2019; Woźniak 2019; Fonseca and Domingues 2018). On the other hand, standardized systems of quality management generate certain costs related to their implementation, maintenance and improvement (Chountalas et al. 2020; Zimon and Dellana 2020). There are studies on the influence of systems in the literature on the subject of quality management on the financial efficiency of the organization (Mokhtar and Muda 2012; Aarts and Vos 2001; Kafel and Simon 2017). However, the results of this research are quite general and it is difficult to clearly define on their basis the degree of influence of systems on particular aspects of financial management. It is therefore necessary to conduct more in-depth research on the impact of standardized quality 
management systems for operation of particular aspects of financial management. The research gap is constituted by a small number of studies on the impact and assessment of the introduction of various types of quality management systems on the financial situation of enterprises, especially those smaller units belonging to the SMEs (small-and medium-sized enterprises) sector. The authors try to prove whether companies using quality management systems manage working capital more effectively.

Working capital is a buffer that protects the enterprise against collapse. It allows one to generate certain funds, reserves that ensure the continuity of functioning in the market. Today, during COVID-19, the units that did not have positive working capital are certainly experiencing difficulty in staying in the market. There are many studies where the authors claim that, without a rational policy of working capital management, it is almost impossible to develop a company (Garcia-Teruel and Martinez-Solano 2007; Deloof 2003).

In view of the above, the purpose of this article is to assess the impact of quality management systems on the level of net working capital in enterprises forming group purchasing organizations (GPOs). The analysis was carried out on a group of 102 commercial enterprises operating in branch GPOs.

\section{Literature Review}

When analyzing the literature in the area of working capital management, one can find information that it has a direct impact on the liquidity of the enterprise (Kim et al. 1998; Opler et al. 1999; Troilo et al. 2019; Corsten and Gruen 2004; Chiou et al. 2006), profitability (Deloof 2003; Ukaegbu 2014; Peng and Zhou 2019) and solvency (Berryman 1983; Peel and Wilson 1994; Magni and Marchioni 2020; Pirttilä et al. 2020; Fazzari and Petersen 1993; Song et al. 2020; Sandberg and Mena 2015). Working capital can be a competitive advantage for companies. In recent years, large corporations have discovered that there are important cash flow streams which they can access if they aggressively manage their working capital accounts (accounts receivable, inventory, settlements and advances (Chauhan 2019; De Almeida and Eid 2014; Chen and Kieschnick 2018; Dalci and Ozyapici 2018). There are authors who claim that working capital allows companies to survive during a crisis (Kasiran et al. 2016; Ding et al. 2013; Tsuruta 2019; Mahmoudzadeh et al. 2018; He et al. 2017).

Working capital management is important because it enables enterprises to free up cash and improve liquidity (Dhole et al. 2019). K. Smith suggests that working capital decisions affect the efficiency and effectiveness of a company (Smith 1980). There are authors who claim that optimal working capital provides financial resources for the ongoing functioning of enterprises (Bian et al. 2018). However, above all, what is important is that efficient working capital management allows for reducing costs and improving profitability (Chauhan 2019). In addition, the research on working capital management showed that higher levels of working capital allowed companies to increase sales (Baños-Caballero et al. 2012, 2014; Almeida and Campello 2007). The authors also state that positive working capital allows for obtaining larger discounts in the case of earlier payments (Deloof 2003). These additional discounts help to improve the competitive positions of enterprises, so they are very important in a situation whereby the entity is fighting hard for a new contractor or is trying to maintain a regular customer. In general, functioning within branch group purchasing organizations allows enterprises to take advantage of such offers (Zimon 2018; Zimon and Zimon 2019). A high level of working capital definitely increases the financial security of enterprises. However, maintaining a very high level entails costs, and it reduces the profits and profitability of the company. There are authors who argue that too high levels of net working capital are in turn just unnecessary, unreasonable costs that the company incurs, which negatively affect the financial result. Bank loans, which are often the source of financing enterprises, are often the main source of financing working capital for many companies (Chen and Kieschnick 2018). Some authors claim that additional financial costs increase the probability of bankruptcy (Kieschnick et al. 2011). It is difficult to disagree with the fact that loans increase costs, but the impact of financial costs on the collapse of enterprises is rather small. In turn, Wang (Wang 2002) states that companies from Japan and Taiwan with a high market position try to maintain low 
levels of net working capital. This is why it is very important when managing working capital to find appropriate management strategies and methods that will facilitate the control of individual components of working capital. Quality management systems and operations within branch group purchasing organizations can be such methods (Zimon 2017a). They can improve the process of managing receivables and inventories.

In addition, the application of quality management systems and the introduction of appropriate procedures allows for streamlining of control processes in the area of receivables, inventories and liabilities. Enterprises using these two methods are able to optimize their working capital management strategies to the one that is right at the moment. In the literature, one can find studies where the authors claim that the introduction of TQM (Total Quality Management), Six improves the functioning of enterprises. The improvement can be seen in processes such as the speed and accuracy of credit approval processes from 24 to $48 \mathrm{~h}$ to a few minutes; full digitization of credit application, approval and invoicing processes without paper; reduction in maintaining sales force records and adherence to processes to increase actual sales time with customers to increase efficiency, making suppliers responsible for inventory availability in warehouses and introducing asset utilization control programs that improved the efficiency of working capital management (Boisjoly et al. 2020).

To date, there are many studies in the literature in which the authors claim that the operation of GPO allows cost reduction (Yang et al. 2017; Blair and Durrance 2014; Nollet et al. 2017) In general, the studies on the functioning of GPO were carried out on large companies operating in the medical industry (Burns and Lee 2008; Hu and Schwarz 2011; Marvel and Yang 2008; Cowan et al. 2016; Zimon 2017b). There are few studies that have analyzed other sectors. There is research in which authors analyze the functioning of GPOs operating in the aviation or automotive industry in terms of cost optimization (Dana 2012). However, in general, in many studies, the authors give maximization of profits thanks to the use of the scale effect as the most important goal of the functioning of GPO units (Schotanus and Telegen 2007; Rozemeijer 2000). In Poland, enterprises operate within the framework of the GPO, especially in the construction industry, primarily to provide SMEs protection against foreign concerns entering the Polish market. Large foreign enterprises are rapidly gaining in the Polish market and quite quickly their entry is leading to the bankruptcy of small weak entities. The construction industry is particularly exposed to such a situation, which is why the first GPOs began to be established in Poland in the 1990s. Of course, the economies of scale and cooperation within GPO, apart from improving financial security, positively affect the financial results of individual units.

\section{Research Methodology}

The research sample included 102 enterprises operating in two Polish branches of group purchasing organizations. The research covered construction industry companies belonging to the largest purchasing groups in Poland whose activities in purchasing groups were formalized and proven. There were 170 enterprises meeting these requirements. The feedback was obtained from 102 . When analyzing the data, it was assumed that the companies that did not disclose their data did not differ significantly in terms of financial results from the companies from which the data were obtained. This assumption underlies, in principle, all partial surveys where there was a "refusal to answer" in some cases. The five oldest purchasing groups in Poland were selected which operated in the industry closely related to the trade in heating and sanitary equipment. Entities operating in the construction industry are particularly exposed to the risk of bankruptcy. On the other hand, GPOs are considered to be organizations that improve operational safety; therefore, research was undertaken in this group of enterprises.

The analyzed enterprises were divided into units that introduced various types of quality management systems. It was a group of 38 enterprises. The second group consisted of 64 companies that did not decide to use quality management systems. Additionally, the group of enterprises using quality management systems was divided into two groups depending on the level of sales. The first group, referred to as A, consisted of 7 enterprises that could be described as large; their average 
turnover exceeded EUR 2 million. The second group consisted of 31 companies with a turnover lower than EUR 2 million. The tests were performed using appropriate statistical methods.

The level of financial ratios in both groups was compared. The results include a compilation of descriptive statistics (mean, median and standard deviation) in each group and an assessment of the significance of differences between the groups using the non-parametric Mann-Whitney test. The choice of the non-parametric test was dictated by quite clear deviations from the normal distribution of some indicators. The Spearman's rank correlation coefficient was also used for the analysis.

On the basis of the conducted research, there were identified those elements which were significantly affected by quality management systems. The areas where quality management systems had no impact were also presented. The analysis was made on the basis of financial data for the years 2017-2019.

\section{Results}

The conducted analysis showed that all enterprises in the analyzed period had positive net working capital. This can be confirmed by the results of the current financial liquidity ratio, which is closely related to the level of net working capital. The detailed results are presented in Table 1.

Table 1. Average results for current financial liquidity ratios in 2016-2018.

\begin{tabular}{|c|c|c|c|c|c|c|c|c|c|c|c|}
\hline \multirow{3}{*}{$\begin{array}{c}\text { Current } \\
\text { Financial } \\
\text { Liquidity } \\
\text { Ratios }\end{array}$} & \multicolumn{10}{|c|}{ Enterprises } & \multirow{3}{*}{$p$} \\
\hline & \multicolumn{5}{|c|}{$\begin{array}{l}\text { Enterprises That Do Not Use } \\
\text { Quality Management Systems }\end{array}$} & \multicolumn{5}{|c|}{$\begin{array}{l}\text { Enterprises That Use Quality } \\
\text { Management Systems }\end{array}$} & \\
\hline & $\bar{x}$ & Me & $s$ & Min & Max & $\bar{x}$ & Me & $s$ & Min & Max & \\
\hline 2017 & 3.01 & 1.83 & 2.88 & 0.78 & 9.0 & 2.41 & 2.12 & 0.61 & 1.50 & 7.1 & 0.4922 \\
\hline 2018 & 3.27 & 1.94 & 3.01 & 1.00 & 14.5 & 2.46 & 2.33 & 0.62 & 1.40 & 8.2 & 0.5067 \\
\hline 2019 & 3.19 & 1.99 & 3.03 & 1.20 & 16.3 & 2.33 & 2.09 & 1.08 & 1.20 & 11.2 & 0.5102 \\
\hline
\end{tabular}

These results confirm that all enterprises have a positive level of net working capital. However, very often, it definitely exceeds the demand for it. While analyzing the results in terms of the demand for net working capital and its actual state, some differences were observed. In both groups, higher working capital levels were observed as compared to the demand. The detailed results between the actual condition and demand are presented in Table 2.

Table 2. Level of working capital (in days).

\begin{tabular}{|c|c|c|c|c|c|c|c|c|c|c|c|}
\hline \multirow{3}{*}{$\begin{array}{c}\text { Level of } \\
\text { Working } \\
\text { Capital }\end{array}$} & \multicolumn{10}{|c|}{ Enterprises } & \multirow{3}{*}{$p$} \\
\hline & \multicolumn{5}{|c|}{$\begin{array}{l}\text { Enterprises That Do Not Use } \\
\text { Quality Management Systems }\end{array}$} & \multicolumn{5}{|c|}{$\begin{array}{c}\text { Enterprises That Use Quality } \\
\text { Management Systems }\end{array}$} & \\
\hline & $\bar{x}$ & Me & $s$ & Min & $\operatorname{Max}$ & $\bar{x}$ & Me & $s$ & Min & $\operatorname{Max}$ & \\
\hline 2017-2019 & 23.4 & 21.1 & 7.2 & 14 & 43 & 11.2 & 10.9 & 11.3 & 8 & 32 & 0.1336 \\
\hline
\end{tabular}

In the majority of enterprises using quality management systems, the level of net working capital slightly exceeds the demand. In enterprises that do not use this system, the difference between actual demand and real ownership is clear. It can, therefore, be concluded that a company using quality management systems manages its net working capital better. Next, the efficiency of managing the most important elements of working capital was assessed. To this end, the operating cycle indicator was used. The detailed results are presented in Table 3. 
Table 3. Average results for the operating cycle ratio (in days).

\begin{tabular}{|c|c|c|c|c|c|c|c|c|c|c|c|}
\hline \multirow{3}{*}{$\begin{array}{c}\text { Operating } \\
\text { Cycle } \\
\text { Ratio }\end{array}$} & \multicolumn{10}{|c|}{ Enterprises } & \multirow{3}{*}{$p$} \\
\hline & \multicolumn{5}{|c|}{$\begin{array}{l}\text { Enterprises That Do Not Use } \\
\text { Quality Management Systems }\end{array}$} & \multicolumn{5}{|c|}{$\begin{array}{l}\text { Enterprises That Use Quality } \\
\text { Management Systems }\end{array}$} & \\
\hline & $\bar{x}$ & Me & $s$ & Min & Max & $\bar{x}$ & Me & $s$ & Min & Max & \\
\hline 2017 & 147 & 141 & 26.2 & 94 & 209 & 130 & 122 & 25.4 & 80 & 190 & 0.2354 \\
\hline 2018 & 152 & 137 & 27.9 & 98 & 212 & 131 & 121 & 23.8 & 83 & 177 & 0.1909 \\
\hline 2019 & 154 & 138 & 26.1 & 90 & 203 & 133 & 126 & 22.5 & 79 & 168 & 0.2001 \\
\hline
\end{tabular}

When assessing the results presented in Table 3 regarding the operational cycle, it is evident that they effectively manage the key elements creating working capital of companies using quality management systems. Details are presented in Table 4 below.

Table 4. Cash conversion cycle (CCC in days).

\begin{tabular}{|c|c|c|c|c|c|c|c|c|c|c|c|}
\hline \multirow{3}{*}{$\mathrm{CCC}$} & \multicolumn{10}{|c|}{ Enterprises } & \multirow{3}{*}{$p$} \\
\hline & \multicolumn{5}{|c|}{$\begin{array}{l}\text { Enterprises That Do Not Use } \\
\text { Quality Management Systems }\end{array}$} & \multicolumn{5}{|c|}{$\begin{array}{c}\text { Enterprises That Use Quality } \\
\text { Management Systems }\end{array}$} & \\
\hline & $\bar{x}$ & Me & $s$ & Min & Max & $\bar{x}$ & Me & $s$ & Min & Max & \\
\hline 2017 & 67 & 60 & 32.5 & 19 & 145 & 52 & 42 & 29.5 & 10 & 144 & 0.5033 \\
\hline 2018 & 68 & 58 & 33.1 & 17 & 150 & 56 & 48 & 27.1 & 22 & 117 & 0.4945 \\
\hline 2019 & 71 & 63 & 31.7 & 18 & 141 & 58 & 47 & 27.4 & 30 & 128 & 0.5137 \\
\hline
\end{tabular}

The next part of the analysis was intended to answer the question of whether the introduction of quality management systems had a significant impact on the basic elements shaping the level of net working capital. The tests were performed using appropriate statistical methods. In tables of descriptive statistics characterizing the distribution of ratios in both groups in particular years, there were such measures as average, standard deviation, median and minimum and maximum. When interpreting the results, it is worth paying attention not only to the average level of ratios in the compared groups but also to the median.

The analysis of turnover ratios for short-term receivables in days, inventories in days and short-term liabilities in days was carried out. The results for the receivables turnover rate in days for 2017 and 2019 was higher in the group of enterprises not using quality management systems; the difference between both groups was close to the level of statistical significance $(p=0.0820)$. The detailed results are presented in Table 5. The enterprises that do not use quality management systems in the research chapter are marked as group A. The enterprises which use quality management systems in the research chapter are marked as group B. 
Table 5. Average results for receivables turnover rates in days.

\begin{tabular}{|c|c|c|c|c|c|c|c|c|c|c|c|}
\hline \multirow{3}{*}{$\begin{array}{c}\text { Receivables } \\
\text { Turnover } \\
\text { Rates in } \\
\text { Days }\end{array}$} & \multicolumn{10}{|c|}{ Enterprises } & \multirow{3}{*}{$p$} \\
\hline & \multicolumn{5}{|c|}{$\begin{array}{l}\text { Enterprises That Do Not Use } \\
\text { Quality Management Systems }\end{array}$} & \multicolumn{5}{|c|}{$\begin{array}{c}\text { Enterprises That Use Quality } \\
\text { Management Systems }\end{array}$} & \\
\hline & $\bar{x}$ & Me & $s$ & Min & $\operatorname{Max}$ & $\bar{x}$ & Me & $s$ & Min & $\operatorname{Max}$ & \\
\hline 2017-2019 & 77.4 & 73.8 & 24.8 & 20 & 148 & 64.5 & 57.3 & 20.4 & 16 & 82 & 0.0820 \\
\hline
\end{tabular}

When assessing the receivables turnover in days, it can be seen that higher results were obtained by entities that do not use quality management systems. The enterprises using quality management systems manage receivables more effectively.

Large differences in the level of averages were observed in the case of the analysis of the liabilities turnover ratio in days (they are not statistically significant as they are relatively small in relation to the variability range of this indicator in each group-standard deviations are large in relation to the difference between groups). However, the presented results indicate that they are quicker to regulate the obligations of the companies using quality management systems. The details are presented in Table 6.

Table 6. Average results for the liabilities rotation ratio in days.

\begin{tabular}{|c|c|c|c|c|c|c|c|c|c|c|c|}
\hline \multirow{3}{*}{$\begin{array}{c}\text { Liabilities } \\
\text { Rotation } \\
\text { Ratio in } \\
\text { Days }\end{array}$} & \multicolumn{10}{|c|}{ Enterprises } & \multirow{3}{*}{$p$} \\
\hline & \multicolumn{5}{|c|}{$\begin{array}{l}\text { Enterprises That Do Not Use } \\
\text { Quality Management Systems }\end{array}$} & \multicolumn{5}{|c|}{$\begin{array}{l}\text { Enterprises That Use Quality } \\
\text { Management Systems }\end{array}$} & \\
\hline & $\bar{x}$ & Me & $s$ & Min & Max & $\bar{x}$ & Me & $s$ & Min & $\operatorname{Max}$ & \\
\hline 2017-2019 & 84.3 & 72.8 & 21.6 & 38 & 147 & 52.6 & 52.2 & 17.4 & 41 & 98 & 0.2019 \\
\hline
\end{tabular}

Inventories were the last of the analyzed items directly affecting financial liquidity. In the case of inventory turnover in days, no statistically significant differences were observed. The detailed results are presented in Table 7.

Table 7. Average results for the inventory turnover ratio in days.

\begin{tabular}{|c|c|c|c|c|c|c|c|c|c|c|c|}
\hline \multirow{3}{*}{$\begin{array}{l}\text { Inventory } \\
\text { Turnover } \\
\text { Ratio in } \\
\text { Days }\end{array}$} & \multicolumn{10}{|c|}{ Enterprises } & \multirow{3}{*}{$p$} \\
\hline & \multicolumn{5}{|c|}{$\begin{array}{l}\text { Enterprises That Do Not Use } \\
\text { Quality Management Systems }\end{array}$} & \multicolumn{5}{|c|}{$\begin{array}{l}\text { Enterprises That Use Quality } \\
\text { Management Systems }\end{array}$} & \\
\hline & $\bar{x}$ & Me & $s$ & Min & Max & $\bar{x}$ & Me & $s$ & Min & Max & \\
\hline 2017-2019 & 78.3 & 70.9 & 18.3 & 48 & 129 & 57.6 & 48.8 & 16.7 & 40 & 95 & 0.4014 \\
\hline
\end{tabular}

The next stage of the research was the division of enterprises using quality management systems according to the turnover. On the basis of the obtained results, it can be concluded that the following ratios are significantly higher in group A of enterprises: financial liquidity, CCC, working capital in current assets and quick ratio (for this ratio, the difference is close to statistically significant) and a lower level of liabilities in group A of enterprises. The detailed results are presented in Table 8. 
Table 8. Descriptive statistics for financial indicators in both groups with results of Mann-Whitney test.

\begin{tabular}{cccccccc}
\hline & \multicolumn{3}{c}{ Group A $(N=7)$} & \multicolumn{3}{c}{ Group B $(N=31)$} & $p$ \\
\cline { 2 - 6 } Financial Indicators & Mean & Median & $\begin{array}{l}\text { Std. } \\
\text { dev. }\end{array}$ & Mean & Median & $\begin{array}{l}\text { Std. } \\
\text { dev. }\end{array}$ \\
\hline Financial liquidity & 2.53 & 2.53 & 0.86 & 1.89 & 1.37 & 1.84 & $0.0152^{*}$ \\
Operation cycle (days) & 133.9 & 126.0 & 34.0 & 139.7 & 142.3 & 35.1 & 0.6852 \\
CCC (days) & 74.8 & 85.0 & 35.4 & 40.9 & 34.0 & 34.8 & $0.0295^{*}$ \\
ROS (\%) & 3.7 & 2.7 & 3.1 & 3.0 & 1.3 & 3.0 & 0.6852 \\
Working capital in current & 57.4 & 66.3 & 17.4 & 35.3 & 29.7 & 25.2 & $0.0239 *$ \\
assets (\%) & 1.23 & 1.30 & 0.47 & 1.00 & 0.73 & 1.01 & 0.0586 \\
Quick & 61.2 & 61.5 & 18.5 & 78.2 & 83.3 & 32.1 & 0.2193 \\
Receivables (days) & 72.6 & 64.5 & 19.1 & 61.5 & 64.3 & 24.4 & 0.4158 \\
Inventories (days) & 59.1 & 62.4 & 12.2 & 98.8 & 91.0 & 41.8 & $0.0082^{* *}$ \\
Liabilities (days) & & & & & & & \\
\hline
\end{tabular}

$p$-value from Mann-Whitney test. ${ }^{*}, * *$.

The chart shows the values of descriptive statistics for selected indicators for which there was a significant difference between the two groups (Figure 1).
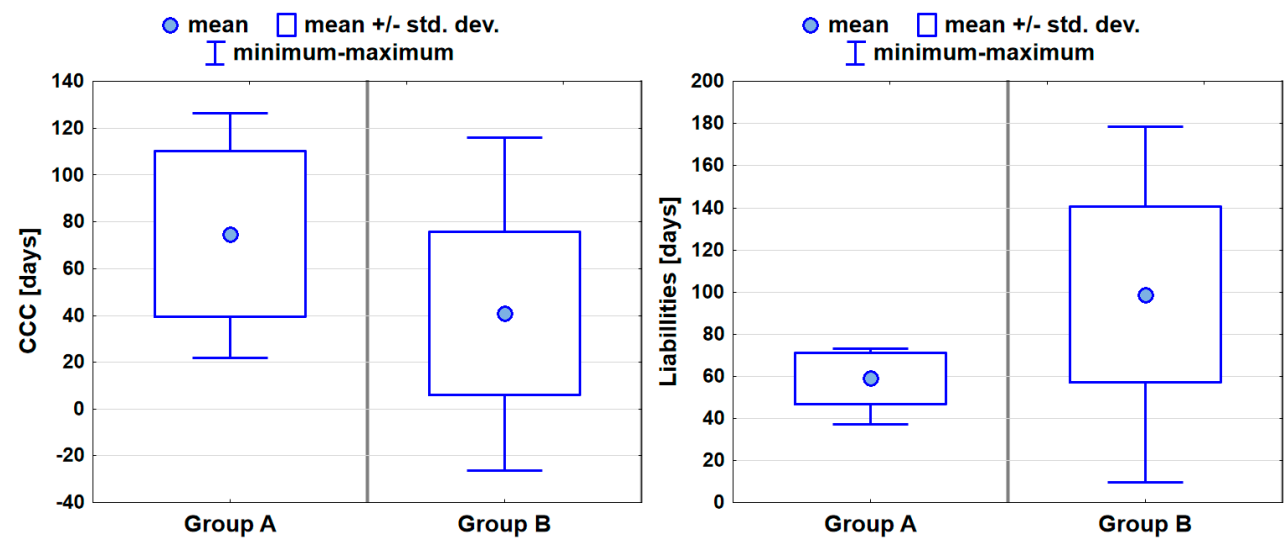

Figure 1. Comparison of CCC and liabilities in group A and B.

The next step was to analyze the correlation in the group of 38 analyzed enterprises using quality management systems.

In group A (for seven companies), the correlations between the working capital in current assets ratio and other important indicators-ROS, CCC, financial liquidity and operation cycle-were examined. Spearman's rank correlation coefficient was used for the analysis. The table shows the values of the correlation coefficient along with the assessment of its statistical significance.

The working capital in current assets ratio was very closely related to financial liquidity $\left(r_{S}=0.86\right)$. Working capital was closely related to the management of working capital, which was confirmed by an overdue analysis. Only this correlation was statistically significant $\left(p=0.0137^{*}\right)$. The correlations of working capital in current assets with the other indicators considered in Table 9 were slightly weaker $\left(r_{S}\right.$ ok. 0.60$)$, but due to the lack of statistical significance, they could not be subjected to deeper interpretation. 
Table 9. Correlation analysis of the share of working capital in financing of current assets ratio with other selected financial indicators.

\begin{tabular}{ccc}
\hline \multirow{2}{*}{ Other Financial Indicators } & \multicolumn{2}{c}{ Share of Working Capital in Financing of Current Assets (\%) } \\
\cline { 2 - 3 } & $\boldsymbol{r}_{\mathrm{S}}$ & $\boldsymbol{p}$ \\
\hline Financial liquidity & 0.86 & 0.0137 \\
Operation cycle (days) & 0.64 & 0.1194 \\
CCC (days) & 0.68 & 0.0938 \\
ROS (\%) & 0.56 & 0.1950 \\
\hline
\end{tabular}

$r_{S}$-Spearman correlation coefficient; $p$-assessment of statistical significance.

The scatter plot (Figure 2) shows the only statistically significant correlation between share of working capital in financing of current assets and financial liquidity.

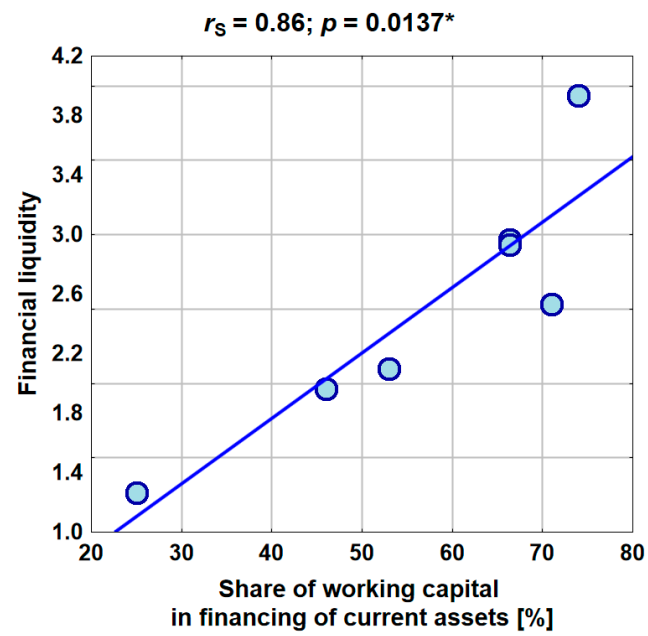

Figure 2. Correlation between share of working capital in financing of current assets and financial liquidity.

\section{Discussion}

The disadvantage of the analysis is the small test sample. However, it covers $90 \%$ of enterprises operating in branch group purchasing organizations that form commercial enterprises. There are many other GPOs in Poland related to this branch, but they also include units from other industries. These types of groups are referred to as multi-branch groups. There are major differences in the management of enterprises that operate in such groups, which is why multi-branch purchasing groups were not included in the conducted research.

There are few publications in the literature on the impact of quality management on the level of working capital (Zimon and Zimon 2019). There is also not much information on the impact of quality management systems on individual components of working capital. In the literature, one can find information on trade credit, which is closely related to receivables from recipients and the issue of the quality of the products sold. According to Long and co-authors (Long et al. 1993), trade credit can be used to distinguish between high- and low-quality products. The literature states that commercial credit is provided by reliable companies whose customers can verify the quality of products before making payments. So, according to this theory, cash payments appear when low-quality goods are sold.

It is worth carrying out further research on enterprises operating in other branches to assess how quality management systems affect the working capital and financial security of enterprises. 


\section{Conclusions}

The conducted research is an introduction to further research on the impact of quality management systems on the level of net working capital. The analysis concerned commercial enterprises operating in branch group purchasing organizations and showed that there were some differences in the level of net working capital in the analyzed groups of enterprises. Capital management is run more efficiently by the enterprises that are supported by a quality management system. This is confirmed by the results regarding the level of working capital and operating cycle. A detailed analysis of the more significant elements affecting the level of net working capital showed that statistically significant differences were observed in the area of short-term receivables management. The units that use quality management systems are faster in pursuit of receivables from customers compared to enterprises that do not use such systems. In the case of inventory management, there were virtually no differences. In the area of managing short-term liabilities, large differences appeared.

In summary, companies with quality management systems charge their receivables faster and therefore have cash with which to pay liabilities to suppliers. They regulate liabilities often before the deadline, which allows them to obtain an additional discount, which reduces costs significantly. Favorable changes can be seen in the most important cost item in commercial enterprises, i.e., the value of sold goods at the purchase price. Cost reduction has a positive effect on profits. If the owners decide to leave some of the profits in an enterprise, then the level of equity that funds the company's assets increases. As a result, positive working capital appears in this group of companies. However, the trick is to keep it at the optimal level. The conducted analysis showed that support for managing the working capital of the quality management system enabled the enterprise to optimize its level in comparison to commercial enterprises that did not decide to implement such management systems.

The analysis carried out in the group of enterprises applying quality management systems showed that the enterprises generating high turnover achieved higher results in the case of financial liquidity ratios, quick ratio, CCC and share of working capital in financing of current assets. Therefore, it can be concluded that the introduction of quality management systems in larger enterprises results in an increase in the financial security of the enterprise. In larger enterprises, the implementation of quality management systems strengthens the management control process of individual areas of the enterprise. The responsibility of employees increases. Very often, ISO 9001 is delegated to employees who only use this system in the enterprise and do not have additional duties. In smaller companies, quality management is often an additional task assigned to an employee. Certainly, this approach makes it difficult to control quality management systems.

A very good example of effective management is the liability turnover ratio in days. Here, the difference between the two groups is clear: liabilities are settled faster in large units. These companies more often and to a greater extent benefit from the economies of scale, joint purchases, which is why they often receive discounts for early payment which they use.

The conducted analysis shows that companies that use quality management systems are able to optimize the level of working capital, which will certainly lead to the improvement of financial results, which constitutes the foundation for further development of enterprises.

The results presented in the article should, however, be treated with a degree of caution since improved financial performance could be attributed to many reasons other than quality management systems certification. Nevertheless, our findings and those of similar researchers do support the view that careful design and implementation of consistent and documented quality management systems contributes to superior financial performance.

Suggestions for future research focus on the evolutionary rather than the revolutionary nature of ISO standard implementation within firms and their supply chains. It is also worth conducting research on the impact of such standards as ISO 50001 or ISO 14001.

Author Contributions: Conceptualization, G.Z.; methodology, G.Z.; formal analysis, G.Z.; data duration, G.Z.; writing-original draft preparation, G.Z. and D.Z.; writing_-review and editing, G.Z. and D.Z. All authors have read and agreed to the published version of the manuscript. 
Funding: This research received no external funding.

Conflicts of Interest: The authors declare no conflict of interest.

\section{References}

Aarts, Frank, and Ed Vos. 2001. The impact of ISO registration on New Zealand firms performance: A financial perspective. The TQM Magazine 13: 180-91. [CrossRef]

Almeida, Heitor, and Murillo Campello. 2007. Financial constraints, asset tangibility, and corporate investment. The Review of Financial Studies 20: 1429-60. [CrossRef]

Baños-Caballero, Sonia, Pedro García-Teruel, and Pedro Martínez-Solano. 2012. How does working capital management affect the profitability of spanish SMEs? Small Business Economics 39: 517-29. [CrossRef]

Baños-Caballero, Sonia, Pedro García-Teruel, and Pedro Martínez-Solano. 2014. Working capital management, corporate performance and financial constraints. Journal of Business Research 67: 332-38. [CrossRef]

Berryman, Joyce. 1983. Small business failure and bankruptcy, A Survey of the literature. European Small Business Journal 1: 1-12. [CrossRef]

Bian, Yuan, David Lemoine, Thomas Yeung, Nathalie Bostel, Vincent Hovelaque, Jean Viviani, and Fabrice Gayraud. 2018. Dynamic lot-sizing-based profit maximization discounted cash flow model considering working capital requirement financing cost with infiniti production capa city. International Journal of Production Economics 196: 319-32. [CrossRef]

Blair, Roger, and Christiane Durrance. 2014. Group purchasing organizations, monopsony, and antitrust policy. Managerial and Decision Economics 35: 433-43. [CrossRef]

Boisjoly, Rusell, Thomas Conine Jr., and Michael McDonald IV. 2020. Working capital management: Financial and valuation impacts. Journal of Business Research 108: 1-8. [CrossRef]

Burns, Lawton, and Andrew Lee. 2008. Hospital purchasing alliances: Utilization, services, and performance. Health Care Management Review 33: 203-15. [CrossRef]

Chatzipetrou, Evrikleia, and Odysseas Moschidis. 2017. An exploratory analysis of quality costing in Greek F\&B enterprises. The TQM Journal 29: 324-41.

Chauhan, Gaurav Singh. 2019. Are working capital decisions truly short-term in nature? Journal of Business Research 99: 238-53. [CrossRef]

Chen, Chongyang, and Robert Kieschnick. 2018. Bank credit and corporate working capital management. Journal of Coporate Finance 48: 2018. [CrossRef]

Chiarini, Andrea, Paola Castellani, and Chiara Rossato. 2020. Factors for improving performance in ISO 9001 certified small- and medium-sized service enterprises. The TQM Journal 32: 21-37. [CrossRef]

Chiou, Jeng-Ren, Li Cheng, and Han-Wen Wu. 2006. The determinants of working capital management. Journal of American Academy of Business 10: 149-55.

Chountalas, Panos, Anastasios I. Magoutas, and Eleni Zografaki. 2020. The heterogeneous implementation of ISO 9001 in service-oriented organizations. The TQM Journal 32: 56-77. [CrossRef]

Cicea, Claudiu, Ion Popa, Corina Marinescu, and Simona Stefan. 2019. Determinants of SMEs' performance: Evidence from European countries. Economic Research-Ekonomska Istrazivanja 32: 1602-20. [CrossRef]

Corsten, Daniel, and Thomas Gruen. 2004. Stock-outs cause walk outs. Harvard Business Review 82: 26-28.

Cowan, Anne, Sarrah Clark, Jennifer Gordon, Karin Bok, and Angela Shen. 2016. Vaccine purchasing groups in the United States: An overview of their policies and practices. Vaccine 34: 5060-65. [CrossRef]

Dalci, IIhan, and Hasan Ozyapici. 2018. Working capital management policy in health care: The effect of leverage. Health Policy 122: 1266-72. [CrossRef]

Dana, James, Jr. 2012. Buyer groups as strategic commitments. Games and Economic Behavior 74: 470-85. [CrossRef]

De Almeida, Juliano, and William Eid Jr. 2014. Access to finance, working capital management and company value: Evidences from Brazilian companies listed on BM\&FBOVESPA. Journal of Business Research 67: 924-34.

Dellana, Scott, John Kros, Mauro Falasca, and William J. Rowe. 2019. Risk management integration and supply chain performance in ISO 9001-certified and non-certified firms. International Journal of Productivity and Performance Management 69: 1205-25. [CrossRef]

Deloof, Marc. 2003. Does working capital management affect profitability of Belgian firms? Journal of Business Finance and Accounting 30: 573-88. [CrossRef] 
Dhole, Sandip, Sagarika Mishra, and Ananda M. Pal. 2019. Efficient working capital management, financial constraints and firm value: A text-based analysis. Pacific-Basin Finance Journal 58: 101212. [CrossRef]

Ding, Sai, Alessandra Guariglia, and John Knight. 2013. Investment and financing constraints in China: Does working capital management make a difference? Journal of Banking \& Finance 37: 490-507.

Fazzari, Steven, and Bruce Petersen. 1993. Working capital and fixed investment: New evidence on financing constraints. Rand Journal Economics 24: 328-42. [CrossRef]

Fonseca, Luis, and Pedro Domingues. 2018. Empirical research of the ISO 9001: 2015 transition process in Portugal: Motivations, benefits, and success factors. Quality Innovation Prosperity 22: 16-45. [CrossRef]

Garcia-Teruel, Pedro, and Pedro Martinez-Solano. 2007. Effects of working capital management on SME profitability. International Journal Managerial Finance 3: 164-77. [CrossRef]

He, Wai, Tarun Mukherjee, and Kent Baker. 2017. The effect of the split share structure reform on working capital management of Chinese companies. Global Finance Journal 33: 27-37. [CrossRef]

$\mathrm{Hu}$, Qiaohai, and Leroy Schwarz. 2011. Controversial Role of GPOs in Healthcare-Product Supply Chains. Production and Operations Management Society 20: 1-15. [CrossRef]

Kafel, Piotr, and Andrea Simon. 2017. The reasons for decertification of ISO 9001: Financial aspects. Quality Innovation Prosperity 21: 173-84. [CrossRef]

Kasiran, Farrah, Azhar Mohamad, and Othman Chinc. 2016. Working Capital Management Efficiency: A Study on the Small Medium Enterprise in Malaysia. Procedia Economics and Finance 35: 297-303. [CrossRef]

Kieschnick, Robert, Mark LaPlante, and Rabith Moussawi. 2011. Working capital management and shareholder wealth. Rev. Finance 17: 1827-52. [CrossRef]

Kim, Chang-Soo, David Mauer, and Ann E. Sherman. 1998. The determinants of corporate liquidity: Theory and evidence. Journal Financial Quantitative Analysis 33: 335-59. [CrossRef]

Ključnikov, Aleksandr, Ladislav Mura, and David Sklenár. 2019. Information security management In Smes: Factors of Success. Entrepreneurship and Sustainability Issues 6: 2081-94. [CrossRef]

Kontus, Eleonora, and Damir Mihanovic. 2019. Management of liquidity and liquid assets in small and medium-sized enterprises. Economic Research-Ekonomska Istrazivanja 32: 3247-65. [CrossRef]

Long, Michael, Ileen Malitz, and Abraham Ravid. 1993. Trade credit, quality guarantees, and product marketability. Financial Management 22: 117-27. [CrossRef]

Magni, Carlo, and Andrea Marchioni. 2020. Average rates of return, working capital, and NPV-consistency in project appraisal: A sensitivity analysis approach. International Journal of Production Economics 229: 107-769. [CrossRef]

Mahmoudzadeh, Amineh, Masoud Nili, and Farhad Nili. 2018. Real effects of working capital shocks: Theory and evidence from micro data. The Quarterly Review of Economics and Finance 67: 191-218. [CrossRef]

Marvel, Howard, and Huanxing Yang. 2008. Group purchasing, nonlinears, and oligopoly. International Journal of Industrial Organization 26: 1090-105. [CrossRef]

Mokhtar, Mohd Zulkifli, and Mohd Shaladdin Muda. 2012. Comparative study on performance measures and attributes between ISO and non-ISO certification companies. International Journal of Business and Management 7: 185. [CrossRef]

Nollet, Jean, Martin Beaulieua, and Nathalie Fabbe-Costes. 2017. The impact of performance measurement on purchasing group dynamics: The Canadian experience. Journal of Purchasing and Supply Management 23: 17-27. [CrossRef]

Opler, T., Lee Pinkowitz, Rene Stulz, and Rohan Williamson. 1999. The determinants and implications of corporate cash holdings. Journal Financial Economics 52: 3-46. [CrossRef]

Otrusinova, Milena, and Alena Kulleova. 2019. Liquidity Values in Municipal Accounting in the Czech Republic. Journal of Competitiveness 11: 84-98. [CrossRef]

Peel, Michael, and Nicholas Wilson. 1994. Working capital and financial management practices in the Small Firm sector. International Small Business Journal 14: 1-10. [CrossRef]

Peng, Juan, and Zhili Zhou. 2019. Working capital optimization in a supply chain perspective. European Journal of Operational Research 277: 3846-56. [CrossRef]

Pirttilä, Miia, Veli Matti, Virolainen Lotta Lind, and Timo Kärri. 2020. Working capital management in the Russian automotive industry supply chain. International Journal of Production Economics 221: 1-20. [CrossRef] 
Rozemeijer, Frank. 2000. How to manage corporate purchasing synergy in a decentralised company? Towards design rules for managing and organising purchasing synergy in decentralised companies. European Journal of Purchasing \& Supply Management 6: 5-12.

Sandberg, Erik, and Carlos Mena. 2015. Exploring strategic strengths and weakness of retail purchasing groups. The International Review of Retail, Distribution and Consumer Research 25: 276-97. [CrossRef]

Schotanus, Fredo, and Jan Telegen. 2007. Developing a typology of organisational forms of cooperative purchasing. Journal of Purchasing and Supply Management 1: 53-68. [CrossRef]

Smith, Keith. 1980. Profitability versus liquidity tradeoffs in working capital management. In Readings on the Management of Working Capital. Edited by K. V. Smith. Eagan: West Publishing Company.

Sofiina, Elena. 2020. Modern systemwide processes of quality management in agricultural tenure at the regional level. International Journal for Quality Research 14: 455-70. [CrossRef]

Song, Hua, Xuan Yang, and Kangkang Yu. 2020. How do supply chain network and SMEs' operationalcapabilities enhance working capital financing? An integrative signaling view. International Journal of Production Economics 220: 1-22. [CrossRef]

Susilowati, Lina, Candra Ananda, Khusnul Ashar, and Susilo Susilo. 2020. Labour productivity in micro and small industries (research on leather craftsmen in magetan regency. International Journal for Quality Research 14: 111-28. [CrossRef]

Troilo, Michael, Brian R. Walkup, Masato Abe, and Seulki Lee. 2019. Legal systems and the financing of working capital. International Review of Economics \& Finance 64: 641-56.

Tsuruta, Daisuke. 2019. Working capital management during the global financial crisis: Evidence from Japan. Japan and the World Economy 49: 206-19. [CrossRef]

Ukaegbu, Ben. 2014. The significance of working capital management in determining firm profitability: Evidence from developingeconomies in Africa. Research in International Business and Finance 31: 1-16. [CrossRef]

Wang, Yung-Jang. 2002. Liquidity management, operating performance, and corporate value: Evidence from Japan and Taiwan. Journal of Multinational Financial Management 12: 159-69. [CrossRef]

Woźniak, Joanna. 2019. Identification of Mass Event Customers and Factors Exerting Influence upon their Satisfactionwith Participation in an Event. Quality Access Success 20: 22-26.

Yang, Yu, Hsing Cheng, Chao Ding, and Shengli Li. 2017. To join or not to join group purchasing organization: A vendor's decision. European Journal of Operational Research 258: 581-89. [CrossRef]

Zimon, Dominik, and Grzegorz Zimon. 2019. The impact of implementation of standardized quality management systems onmanagement of liabilities in group purchasing organizations. Quality Innovation Prosperity 23: 60-73. [CrossRef]

Zimon, Dominik, and Scott Dellana. 2020. A longitudinal exploratory study of ISO 9001 certification abandonment in small- and medium-sized enterprises. International Journal of Quality \& Reliability Management 37: 53-67.

Zimon, Dominik. 2017a. The influence of quality management systems for improvement of logistics supply in Poland. Oeconomia Copernicana 8: 643-55. [CrossRef]

Zimon, Dominik. 2017b. Quality Management Systems' impact on the functioning of distribution channels in the FMCG market. Quality Access to Success 18: 52-57.

Zimon, Grzegorz. 2018. Influence of group purchasing organizations on financial situation of Polish SMEs. Oeconomia Copernicana 9: 87-104. [CrossRef]

(C) 2020 by the authors. Licensee MDPI, Basel, Switzerland. This article is an open access article distributed under the terms and conditions of the Creative Commons Attribution (CC BY) license (http://creativecommons.org/licenses/by/4.0/). 